Dinamika Sosial Budaya, Vol 22, No. 1, Juni 2020, pp 1-7

p-ISSN: 1410-9859\& e-ISSN: 2580-8524

http://journals.usm.ac.id/index.php/jdsb

\title{
PEREKAT IDENTITAS INDONESIA DI TENGAH ARUS RIVALITAS MENYONGSONG PILKADA SERENTAK TAHUN 2020
}

\author{
Kukuh Setyo Pambudi \\ kukuhpambudi@ymail.com \\ Damai Dan Resolusi Konflik Universitas Pertahanan \\ Maryanti \\ maryantimiharjo@gmail.com \\ Damai Dan Resolusi Konflik Universitas Pertahanan \\ Endri Ahmadi \\ thedomlank@gmail.com \\ Damai Dan Resolusi Konflik Universitas Pertahanan
}

\begin{abstract}
ABSTRAK
Pemilu tahun 2020 merupakan salah satu rangkaian Pemilihan Umum yang akan digelar di Indonesia dengan aroma rivalitas kental setelah beberapa Pemilu yang telah berlangsung dan mengakibatkan konflik sosial. Tulisan ini berusaha memberikan deskripsi tentang rivalitas yang dapat terjadi selama Pilkada serentak 2020 dan mengambarkan akibat yang mungkin terjadi di tengah masyarakat. Kemudian tulisan ini juga berusaha memberikan sebuah deskripsi tentang pemaknaan identitas nasional Indonesia sebagai sebuah perekat. Identitas adalah sebuah penghayatan suatu individu, kelompok, atau bangsa atas dirinya yang menjadi gambaran utuh tentang dirinya. Identitas memiliki peranan sentral dalam tegaknya suatu individu dan bangsa dalam menatap masa depannya juga berdamai dengan masa lalu. Oleh karena itu, penulis berpendapat bahwa menegaskan identitas nasional merupakan bentuk reintegrasi kebangsaan yang mulai retak akibat adanya arus rivalitas dan menyongsong digelarnya Pilkada serentak 2020. Nantinya identitias juga dapat menghindarkan bangsa Indonesia dalam pusaran konflik sosial yang dapat terjadi apabila rivalitas tidak terbendung.
\end{abstract}

Kata kunci: Pilkada serentak 2020, identitas nasional, rivalitas, konflik sosial. 
Dinamika Sosial Budaya, Vol 22, No. 1, Juni 2020, pp 1-7

p-ISSN: 1410-9859\& e-ISSN: 2580-8524

http://journals.usm.ac.id/index.php/jdsb

\section{PENDAhuluan}

Saat ini perpolitikan Indonesia telah memasuki masa baru jabatan pemerintahan kedua Presiden Joko Widodo atau Jokowi. Terpilihnya kembali Jokowi ini tidak dapat dipisahkan dengan salah satu pemilihan umum (pemilu) terbesar di Indonesia pada 17 April 2019 lalu. Sesuai dengan Undang-Undang No. 7 Tahun 2017 tentang Pemilihan Umum, Pemilu 2019 menjadi salah satu pemilu terbesar yang pernah dilaksanakan di Indonesia karena dilakukan secara serentak. Terdapat lima jenis pemungutan suara pada pemilu tahun ini yaitu untuk memilih pasangan calon presiden dan wakil presiden, anggota DPR RI, anggota DPRD provinsi, anggota DPRD kabupaten/kota, dan anggota DPD dalam waktu bersamaan.

Pada pemilu tahun 2019 ini, Pemilihan presiden (Pilpres) menjadi peristiwa yang paling menarik perhatian publik baik domestik maupun luar negeri. Indonesia memiliki pengalaman pilpres yang memecah belah masyarakat Indonesia pada tahun 2014 dan tahun 2019 dengan hanya dua penantang yaitu Joko Widodo dan Prabowo Subianto. Sebagai negara dengan mayoritas penduduk Muslim terbesar, praktik yang dilakukan kebanyakan masyarakat Indonesia dengan bentuk Islam moderat. Namun pada pilpres terakhir telah jelas tergambarkan polarisasi masyarakat dengan meningkatnya politik identitas yang mewarnai perkembangan proses politik domestik di Indonesia.

Citra yang terbangun ataupun sengaja dibangun oleh Jokowi dan Prabowo sendiri sangat bertentangan. Jika pada masa awal pemerintahan pertama Jokowi dikenal sebagai sosok dari kalangan sipil, Prabowo dikenal sebagai tokoh militer. Sebagai lawan politik, Prabowo membangun koalisi dengan kelompok Islam garis keras yang membuat Jokowi memilih Ma'ruf Amin yang merupakan seorang ulama konservatif sebagai pasangannya dalam pemilu. Walaupun penunjukkan calon wakil dari kalangan ulama cukup meredakan tuduhan jika Jokowi tidak terlalu islami, tetapi hal ini justru semakin menekankan politik identitas. Dengan demikian, isu 'agama' dan identitas sosial semakin dimainkan dalam politik praktis.

Rivalitas antara dua kubu tidak terjadi secara tiba-tiba karena pada tahun 2012, keduanya pernah berkoalisi untuk memenangkan suara pada pemilihan kepala daerah (Pilkada) DKI Jakarta 2012. Pada waktu itu, terjadi koalisi antara Partai Demokrasi Indonesia Perjuangan (PDI-P) dan Partai Gerindra sebelum bersaing sengit dalam pilpres 2014 dan 2019. Hal tersebut dimungkinkan karena salah satu pasangan calon gubernur dan wakil gubernur yaitu Jokowi merupakan kader PDI-P dan Basuki Tjahaja Purnama (Ahok) sebagai kader Partai Gerindra. Sebagai Ketua Umum Dewan Pembina Pusat Partai Gerindra, Prabowo Subianto bukan hanya mendukung pencalonan keduanya tetapi juga menyebutkan bahwa Jokowi-Ahok merupakan figur pemimpin bersih (Wahono, 2012). Untuk pertama kalinya muncul tokoh minoritas (Ahok) yang memimpin Jakarta sebagai representasi Indonesia.

Persaingan sengit antara Jokowi dan Prabowo dimulai ketika keduanya sama-sama mengajukan diri sebagai calon presiden pada pilpres 2014. Pada pilpres ini, persaingan tidak hanya terjadi antara elit politik tetapi juga pendukung masing-masing calon presiden. Slogan yang berkembang dalam masyarakat seperti 'Salam Dua Jari' digunakan sebagai penanda pendukung Jokowi-JK yang dibalas dengan 'Salam Gigit Jari' untuk menyerang pendukung Jokowi. Pada pilpres 2014 tersebut diwarnai oleh drama politik ketika kedua calon sama-sama mengklaim kemenangan hingga gugatan kubu Prabowo terhadap hasil pilpres ke Mahkamah Konstitusi (MK). Pada akhirnya Joko Widodo yang saat itu berpasangan dengan Jusuf Kalla (JK) menang dengan raihan $53,15 \%$ suara atau unggul dengan selisih 6,3\% dari pasangan Prabowo Subianto - Hatta Rajasa dengan perolehan $46,85 \%$ suara secara nasional (Kusnandar, 2019).

Pilpres 2019 kembali mempertemukan Jokowi dan Prabowo sebagai rival politik untuk merebut kursi RI 1. Seperti mengulang pilpres 2014, masyarakat Indonesia seolah hanya mempunyai dua pilihan politik sebagai 'cebong atau kampret' hingga 'komunis atau Islam'. Sama halnya dengan pilpres sebelumnya, pilpres 2019 ini juga disertai drama politik klaim kemenangan sampai kembalinya kubu Prabowo menggugat hasil pilpres ke Mahkamah Konstitusi (MK). Hasil 
Dinamika Sosial Budaya, Vol 22, No. 1, Juni 2020, pp 1-7

p-ISSN: 1410-9859\& e-ISSN: 2580-8524

http://journals.usm.ac.id/index.php/jdsb

pilpres 2019 kembali menempatkan Jokowi yang kali ini berpasangan dengan Ma'ruf Amin sebagai pemenang pemilu dengan capaian 85.607.362 suara atau 55,50\%. Pasangan Jokowi-Ma'ruf unggul $11 \%$ dari pasangan Prabowo Subianto-Sandiago Uno yang mendapatkan 68.650.239 suara atau 44,50\% (Komisi Pemilihan Umum, 2019).

Walaupun terdapat upaya rekonsiliasi antara Jokowi dan Prabowo pasca pilpres 2019, kondisi masyarakat Indonesia masih dalam kondisi yang terpolarisasi. Kompromi politik dengan masuknya Prabowo ke dalam kabinet pemerintahan kedua Jokowi tidak serta merta menyelesaikan konflik sosial di akar rumput. Polarisasi masyarakat pada level bawah ini tentu berbahaya apalagi Indonesia akan menghadapi Pilkada serentak pada tahun 2020. Politik identitas yang telah kuat dengan adanya pilpres 2019 dapat semakin menguat dengan munculnya isu tentang kedaerahan dan 'putra daerah'. Belum lagi dengan adanya rencana untuk diselenggarakannya Pilkada serentak pada tahun 2020 maka perlu pengkajian mendalam tentang sejauh mana dampak yang masih tersisa. Hal ini bukan tanpa sebab, karena sesungguhnya pihak yang paling tereksplorasi baik secara emosi maupun rivalitas adalah kalangan masyarakat paling bawah.

Pembelahan hanya akan membuat identitas Indonesia makin terkoyak. Pemilu yang singkat namun berdampak besar harus mendapatkan perhatian yang besar dalam pengelolaan kehidupan sosial di dalam masyarakat. Dengan demikian, maka penting untuk mengetahui dampak politik identitas yang disebabkan oleh Pemilu 2019 dalam hal ini pemilihan presiden dan bagaimana dampaknya dalam menyongsong Pilkada 2020.

\section{PEMBAHASAN}

\subsection{PEMBELAHAN MASYARAKAT PASCA PEMILU}

Pada beberapa tahun terakhir, perkembangan politik domestik semakin banyak mengancam persatuan dan kesatuan yang dicita-citakan oleh para founding fathers Indonesia. Perkembangan politik telah menjadi tantangan bagi keberlangsungan 4 pilar Indonesia yaitu Pancasila, Undang-Undang Dasar Negara Republik Indonesia (UUD NRI) tahun 1945, Bhinneka Tunggal Ika dan Negara Kesatuan Republik Indonesia (NKRI). Indonesia tengah dihadapkan pada ancaman konflik sosial yang dikatikan dengan perbedaan identitas seperti agama, etnis, kesenjangan sosial dan ekonomi hingga otonomi daerah. Topik konflik identitas masih menjadi isu laris dalam politik dan kehidupan sehari-hari masyarakat.

Dengan adanya politik identitas, maka akan muncul suara-suara yang coba memberikan pengaruh tentang kebesaran suatu kelompok dan menjatuhkan kelompok yang lainnya demi satu tujuan. Tujuan dari suatu kelompok ini bisa saja menjadikan kelompoknya lebih baik atau bertujuan melawan kelompok lain sebagai musuh. Pandangan bagaimana anggota memandang kelompoknya sendiri dan kelompok lainnya dapat dipengaruhi oleh bias. Bias dengan menganggap kelompoknya lebih baik atau superior terhadap kelompok lain dapat memicu gesekan di antara masyarakat. Selain itu, identitas kelompok yang terlalu dominan juga menjadi salah satu permasalahan. Hal ini dapat menghambat atau bahkan menghancurkan sama sekali toleransi dalam masyarakat yang sebenarnya telah lama tebangun.

Pembahasan dampak pemilu 2019 tidak dapat dipisahkan dari Pilpres 2014 ketika polarisasi masyarakat semakin jelas terlihat berkaitan dengan preferensi politik bukan hanya pada konteks politik nasional tetapi juga daerah. Dengan terpilihnya Jokowi sebagai pemenang pilpres 2014, maka Ahok yang semula sebagai wakil gubernur naik jabatan menggantikannya sebagai gubernur DKI Jakarta. Isu yang terjadi kemudian adalah adanya anggapan kelompok mayoritas (Islam garis keras) yang tidak setuju dipimpin oleh kalangan minoritas. Oleh karena itu, ketika Ahok-Djarot mencalonkan diri, Pilkada DKI Jakarta 2017 disertai isu SARA dan sentimen identitas yang juga merembet ke daerah lain. Puncaknya adalah muncul dikotomi antara 'Islam vs non Islam' atau 'Pribumi vs non Pribumi' yang menjadi gesekan dan memecah belah publik berdasarkan identitasnya.

Dikotomi masyarakat tersebut semakin terealisasi dengan adanya demo berjilid yang dimulai dengan aksi 2 Desember 2016 atau Aksi 212 sebagai penolakan terhadap Ahok. Menurut Lembaga Survei 
Dinamika Sosial Budaya, Vol 22, No. 1, Juni 2020, pp 1-7

p-ISSN: 1410-9859\& e-ISSN: 2580-8524

http://journals.usm.ac.id/index.php/jdsb

Indonesia (LSI) terdapat peningkatan intoleransi sejak 2016 hingga 2018. Dengan margin of error sebesar $2,6 \%$ pada tingkat kepercayaan $95 \%$ disebutkan sebagai hasil survei bahwa Aksi 212 bukan sebagai puncak radikalisme tetapi justru membuka naiknya intoleransi (Komara, 2018). Survei nasional yang dilakukan oleh LSI dan Burhanuddin Muhtadi dari Indikator Politik Indonesia pada Agustus 2018 dengan 1.520 respon tersebut mengkategorikan intoleransi menjadi dua dimensi yaitu intoleransi religius kultural dan intoleransi politik (Muhtadi, 2018). Jika intoleransi religius kultural berkaitan dengan tanggapan terhadap pemeluk agama lain melakukan kegiatan keagamaan, intoleransi politik terkait dengan resistensi terhadap pemeluk agama lain menjadi pemimpin.

Selain pilkada DKI Jakarta tahun 2017, Pilkada Jawa Barat tahun 2018 juga menjadi salah satu peristiwa yang menunjukkan bagaimana kondisi politik daerah dapat mempengaruhi politik secara nasional. Pasangan calon gubernur dan wakil gubernur Sudrajat - Ahmad Syaik (Asyik) membuat debat pilgub Jawa Barat tahun 2018 berakhir dengan panas. Dengan mengeluarkan kaus bertuliskan '2018 Asyik Menang 2019 Ganti Presiden', aksi ini mendapatkan berbagai reaksi baik dari pendukung dan lawan politik. Bahkan KPU Jawa Barat juga melayangkan surat teguran kepada pasangan calon yang diusung oleh Partai Gerindra, Partai Keadilan Sosial (PKS), dan Partai Amanat Nasional (PAN) karena dinilai tidak mematuhi prosedur debat kandidat (Solehudin, 2018). Pasca kejadian, gerakan \#2019GantiPresiden menjadi gerakan dari lawan politik pemerintahan Joko Widodo yang kemudian erat dengan pendukung Prabowo Subianto.

Munculnya sebutan cebong untuk pendukung Jokowi dan kampret yang merujuk pada pendukung Prabowo memperlihatkan buruknya polarisasi politik di Indonesia pada saat dan pasca pemilu 2019. Dengan adanya sebutan ini memperlihatkan bahwa perpolitikan di Indonesia telah membagi masyarakat pada dua kelompok besar. Masalah yang kemudian muncul adalah, kedua kubu tidak hanya berusaha untuk menjadi pemenang dalam pemilu tetapi juga berlomba untuk memperlihatkan diri sebagai korban dalam persaingan yang tidak sehat. Serangan hoax ke Jokowi dianggap lebih besar dari Prabowo terkait dengan 10 isu yaitu isu Ratna Sarumpaet, Utang Pemerintah, Kontainer Surat Suara, E-Toll dari utang Tiongkok, EKTP Palsu dari Tiongkok, Jokowi dituduh PKI, Konsultan Asing, Ijazah SMA Jokowi palsu, 10 juta TKA Tiongkok dan Ma'ruf Amin diganti Ahok (Taufan, 2019). Di sisi lain, Prabowo juga dianggap sebagai korban publikasi pemberitaan yang tidak berimbang karena posisinya sebagai oposisi.

Walaupun pilpres 2019 telah selesai, persaingan antara pendukung Jokowi dan Prabowo masih terasa hingga saat ini. Dengan masuknya Prabowo ke dalam jajaran Kabinet Indonesia Maju, kompromi politik belum dapat menyelesaikan permasalahan di akar rumput. Hal yang kemudian terjadi adalah rivalitas antara pendukung Joko Widodo sebagai Presiden RI dan pendukung Prabowo Subianto sebagai Menteri Pertahanan yang merupakan posisi penting dalam perpolitikan Indonesia. Persaiangan ini tidak dapat dipisahkan dari peran media yang memposisikan kedua tokoh sebagai rival sejak pilpres 2014.

\subsection{IDENTITAS INDONESIA}

NASIONAL

Indonesia adalah negara yang sangat besar dengan banyaknya bangsa menjadi bagian di dalamnya. Sebagai sebuah keniscayaan, kebesaran Indonesia menuntut sebuah konsepsi tentang identitas yang berperan untuk merekatkan tiap komponen bangsa dalam bingkai persatuan. Hal ini penting untuk dijadikan sebuah pertimbangan, oleh karena Indonesia telah mengalami banyak sekali konflik sosial di tengah masyarakat yang dimulai dari lunturnya identitas nasional. Jika merujuk dalam konteks Pemilu, identitas nasional seolah bukan lagi menjadi sebuah kenyataan yang menyatukan, namun mulai ditinggalkan demi rivalitas semata.

Identitas merupakan sebuah konsep yang abstrak yang berasal dari imajinasi individu atau kelompok dalam menghayati dirinya atau kelompoknya. Sutrisno dan Putranto (2004) menjelaskan bahwa identitas merupakan sesuatu yang melekat dalam jati diri suatu bangsa yang dibangun dari perjalanan panjang bangsa tersebut. Hal ini membentuk kesan bahwa sessungguhnya 
Dinamika Sosial Budaya, Vol 22, No. 1, Juni 2020, pp 1-7

p-ISSN: 1410-9859\& e-ISSN: 2580-8524

http://journals.usm.ac.id/index.php/jdsb

identitas memiliki nilai yang sangat dalam karena selain penghayatan, ia juga memiliki nilai sejarah yang kental dan mengakar karena berasal sejak dalam proses pembentukan bangsa. Oleh karena itu, kehilangan identitas nasional, dapat menjadi salah satu bencana yang besar dalam kehidupan masyarakat, atau dalam skala yang lebih besar dapat memulai hancurnya suatu negara.

Kondisi sebuah bangsa dengan identitas yang kuat dapat menjadi sebuah kekuatan yang ditakuti oleh bangsa lain karena identitas layaknya sebuah perekat yang merekatkan kekuatan kecil menjadi satu kesatuan. Anshoriy (2008) menjelaskan dalam sebuah kegagalan suatu bangsa dalam bertahan menghadapi tantangan dan ancaman, selalu diawali oleh kegagalannya dalam menjadi atau bahkan mencari identitas kebangsaannya. Oleh karena itu, menjaga identitas yang sudah ada, merupakan salah satu langkah strategis dalam mempertahankan bangsa Indonesia. Identitas juga merupakan sebuah senjata ampuh, jika merunut sejarah perang dunia ke 2 , bagaimana Jerman dapat bangkit setelah perang dunia pertama.

Salah satu konsep psikologi sosial menjelaskan tentang konsep identitas sebagai suatu sosial yang melekat dalam kehidupan individu dalam masyarakat. Konsep ini kemudian dikenal dengan social identity theory yang dikemukakan oleh beberapa ahli psikologi sosial. Salah satu pencetusnya Hogg dan Abrams (1988) menjelaskan identitas sosial adalah keterikatan seseorang atau sekelompok orang dalam satu identitas tertentu. Konsep ini kemudian terus berkembang, dan kembali disempurnakan oleh Stets dan Burke (2000) sebagai sebuah pengkategorian diri kedalam satu kelompok sosial tertentu yang berakibat pada pembagian tugas dan tanggung jawab dalam kelompok yang dipilih tersebut. Identitas ini juga melekat dan membuat seseorang memiliki sebuah konsep yang meningkatkan self-esteem seseorang.

Identitas sosial ini membuat seseorang yang dalam satu kelompok tertentu merasa menjadi bagian dari kelompok dan merasa bertanggung jawab atas apa yang menjadi pembagian perannya. Seseorang akan lebih mudah merasakan tanggung jawab atau berbuat sesuatu yang lebih untuk kelompok atau identitas yang dipilihnya. Oleh karena itu, penting membangun identitas sosial dalam rangka memupuk rasa kepemilikan tiap komponen bangsa dalam kehidupan berbangsa. Penelitian yang dilakukan oleh Mubah (2011) membuktikan bahwa revitalisasi identitas merupakan sebuah cara yang efektif dalam mempertahankan sebuah bangsa yang tengah dirudung hegemoni. Hal ini sesungguhnya juga merupakan sesuatu yang tengah terjadi di Indonesia setelah adanya Pemilu tahun 2019 dan menyongsong Pilkada serentak tahun 2020.

Indonesia sesungguhnya telah memiliki sebuah identitas yang berasal dari konsensus bersama. Nation Indonesia sebagai identitas tidak dapat dinafikkan, oleh karena proses terbentuknya yang berasal dari penyatuan visi beragam suku bangsa yang ada di Indonesia. Indonesia adalah sebuah bangsa yang dibuat, dan identitas yang masih baru hal ini dapat dillihat ketika kita membandingkannya dengan identitas bangsa yang lain. Namun, identitas yang berasal dari sebuah kesepakatan adalah sesuatu yang cukup kuat dan dapat mengikat dengan catatan beberapa syarat. Salah satunya adalah membumikan identitas nasional indonesia.

Ide tentang identitas nasional Indonesia perlu untuk dibumikan dan disosialisasikan secara luas di tengah masyarakat. Peluang masyarakat dengan pengetahuan mendalam soal identitas nasionalnya dapat membangun masyarakat yang kuat dalam melawan polarisasi ataupun provokasi. Tak perlu sampai hegemoni, namun kelekatan dapat terbangun cukup dengan kedekatan dan seringnya masyarakat mendengar identitasnya. Perlu langkah yang komprehensif diiringi oleh banyak stakeholder yang memiliki peranan dalam pengelolaan konflik di tengah masyarakat.

Kemudian, pembumian identitas nasional juga harus diiringi kejujuran dalam menceritakan sejarahnya untuk menghindari hegemoni dan bias dalam memahami identitasnya. Kejujuran perlu dibudayakan agar masyarakat dapat memahami secara murni tentang apa yang melekat dalam dirinya. Pemahaman yang jujur adalah sebuah harta yang berharga dalam membangun masyarakat yang bersatu dan jauh dari konflik. Selanjutnya, lekatnya identitas tersebut dapat 
Dinamika Sosial Budaya, Vol 22, No. 1, Juni 2020, pp 1-7

p-ISSN: 1410-9859\& e-ISSN: 2580-8524

http://journals.usm.ac.id/index.php/jdsb

mendorong masyarakat untuk lebih tulus dan total dalam memperjuangkan kepentingan bangsa dan negaranya.

Pemilu 2019 merupakan salah satu tonggak sejarah Indonesia, sebuah pemilihan langsung yang kesekian kalinya terselenggara dan menyisakan banyak api konflik sosial yang masih membara sampai saat ini. Arus rivalitas yang sudah terpupuk sejak lama karena kontestasi politik membuat adanya polarisasi di tengah masyarakat. Salah satu yang paling lekat diingat adalah parade iklan politik yang saling bersaing meraih atensi publik pada beberapa Pemilu silam (Firdaus, 2016). Rivalitas ini terus meruncing hingga menumbuhkan beberapa konflik yang berujung kekerasan dan masih terus eksis sebagai sebuah manifes konflik sosial.

Dalam menghadapi konflik sosial yang masih mungkin terjadi dalam Pilkada tahun 2020, menegakkan identitas nasional Indonesia menjadi penting untuk dilakukan. Hal ini berasal dari pemikiran penulis yang menjadikan identitas sebagai center of gravity atau pusat kepentingan kebangsaan. Keseluruhan urusan kebangsaan seharusnya tidak boleh melewatkan sekat identitas yang telah ada sebelumnya. Oleh karena itu, merevitalisasi konsep identitas nasional Indonesia menjadi lebih jelas adalah salah satu langkah yang dapat dilakukan guna merekatkan kembali masyarakat yang telah terpolarisasi oleh adanya kontestasi yang telah berlangsung. Identitas dapat juga menjadi sebuah jawaban mujarab untuk mengobati luka lama Indonesia yakni perpecahan.

\section{KESIMPULAN}

Indonesia adalah bangsa yang besar oleh sejarahnya dan kenyataan sebagai bangsa yang majemuk. Keniscayaan ini adalah sebuat karunia yang agung apabila dapat dikelola dengan baik. Pemilu selalu menjadi satu sandungan dalam kehidupan demokrasi, karena acapkali menghasilkan rivalitas dan kontestasi yang tidak sehat. Terakhir kali, pemilu juga menumbuhkan polarisasi di tengah masyarakat hingga mengancam kehidupan sosial yang lebih luas. Oleh karena itu, menyonsong Pilkada yang akan dilaksanakan pada tahun 2020, perlu dilakukan langkah strategis guna mengurangi dampak konflik yang dapat terjadi. Salah satu yang dapat dilakukan adalah memperkuat identitas nasional, yakni Indonesia. Identitas nasional dapat menjadi ramuan yang ampuh dalam merekatkan kembali masyarakat yang tengah terpolarisasi dan menjadi penangkal perpecahan yang mungkin akan terjadi.

\section{REFERENSI}

Anshoriy, Ch, M. Nasruddin. (2008). Bangsa gagal: mencari identitas kebangsaan. LKIS PELANGI AKSARA.

Firdaus, F. (2016). Parade Iklan Politik di Tahun Politik: Polarisasi Penggunaan Iklan Untuk Membangun Citra Menuju Pemilu 2014. Turast: Jurnal Penelitian dan Pengabdian (e-Journal), 1(1), 81-94.

Hogg, Michael A. and Dominic Abrams. (1988). Social 1dentifications:A Social Psychology of Intergroup Relations and Group Processes. London: Routledge.

Komara, I. (2018, September 24). Survei LSI: Aksi 212 Buka Keran Naiknya Intoleransi. Retrieved from detikNews: https://news.detik.com/berita/4227025 /survei-lsi-aksi-212-buka-kerannaiknya-intoleransi

Komisi Pemilihan Umum. (2019, November 27). Rekapitulasi Hasil Pemilu. Retrieved from Komisi Pemilihan Umum:

https://pemilu2019.kpu.go.id/\#/ppwp/r ekapitulasi/

Kusnandar, V. B. (2019, April 26). Inilah Perolehan Suara Jokowi dan Prabowo di Pilpres 2014. Retrieved from katadata.co.id: https://databoks.katadata.co.id/datapub lish/2019/04/26/inilah-perolehansuara-jokowi-dan-prabowo-di-pilpres2014

Mubah, A. S. (2011). Revitalisasi identitas kultural Indonesia di tengah upaya 
Dinamika Sosial Budaya, Vol 22, No. 1, Juni 2020, pp 1-7

p-ISSN: 1410-9859\& e-ISSN: 2580-8524

http://journals.usm.ac.id/index.php/jdsb

homogenisasi global. Global \& Strategis, Edisi Khusus, 251-260.

Muhtadi, B. (2018, Desember 20). Menguatnya Intoleransi dan Politik Identitas. Retrieved from Media Indonesia:

https://mediaindonesia.com/read/detail /205379-menguatnya-intoleransi-danpolitik-identitas

Solehudin, M. (2018, Mei 16). KPU: Aksi Sudrajat-Syaikhu '2019 Ganti Presiden' Salahi Prosedur. Retrieved from detikNews: https://news.detik.com/berita-jawabarat/d-4023111/kpu-aksi-sudrajatsyaikhu-2019-ganti-presiden-salahiprosedur

Stets, J. E., \& Burke, P. J. (2000). Identity theory and social identity theory. Social psychology quarterly, 224-237.

Sutrisno, M., \& Putranto, H. (2004). Hermeneutika Pascakolonial: soal identitas. Kanisius.

Taufan, S. A. (2019, Februari 7). Survei PolitikaWave: Serangan Hoax Ke Jokowi Lebih Besar dari Prabowo. Retrieved from JawaPos.com: https://www.jawapos.com/nasional/po litik/07/02/2019/survei-politikawaveserangan-hoax-ke-jokowi-lebih-besardari-prabowo/

Undang-Undang No. 7 Tahun 2017 tentang Pemilihan Umum

Wahono, T. (2012, Maret 20). Prabowo: Jokowi dan Ahok Figur Pemimpin Bersih. Retrieved from Kompas.com. 